\section{Epidemiology of road traffic crashes among long distance drivers in Ibadan, Nigeria}

Adewale Moses Adejugbagbe ${ }^{1}$, Akinola Ayoola Fatiregun ${ }^{1}$, Ambrose Rukewe², Temitope Alonge ${ }^{3}$

1. Department of Epidemiology and Medical Statistics, Faculty of Public Health, University of Ibadan, Ibadan 2. Anaesthetist, Emergency Department, University College Hospital, Ibadan

3. Department of Orthopaedics \& Trauma, University College Hospital, Ibadan)

\section{Abstract}

Background: Road Traffic Crashes (RTCs) are major causes of morbidity and mortality in Nigeria. Few studies in Ibadan have focused on the distribution and determinants of RTC among long distance drivers.

Objective: To describe the distribution of crashes by place, times of occurrence, characteristics of persons involved and identify associated factors.

Methods: A cross-sectional study was carried out among consenting long distance drivers within selected parks in Ibadan. Methods: A coss-sectional study was carried out among consenting long distance drivers within selected parks in lbadan. Results: Respondents (592) were males, with median age of 42.0 years (range 22.0-73.0 years). Secondary education wa the highest level of education attained by $38.0 \%$. About $34.0 \%$ reported current use of alcohol. The life-time prevalence of crashes was $35.3 \%(95 \% \mathrm{CI}=31.5-39.2 \%)$ and $15.9 \%(95 \% \mathrm{CI}=13.1-19.0 \%)$ reported having had at least one episode of crash in the last one year preceding the study. The crash occurred mainly on narrow roads $[32 / 94(34.0 \%)$,$] and bad portion$ of tarred roads [35/94 $(37.2 \%)$,$] with peak of occurrence on Saturdays 18/94 (19.1 \%$,$) . Significantly higher proportion$ of drivers aged $\leq 39$ years $(23.4 \%)$ versus $>39$ years $(11.7 \%)$, those with no education $(29.9 \%)$ versus the educated $(13.8 \%)$ and those who reported alcohol use (21.9\%) versus non users $(12.8 \%)$ were involved in crashes in the year preceding the study. Significant predictor of the last episode of crashes in the last one year were age ( $\mathrm{OR}=2.2,95 \% \mathrm{CI}=1.4-3.5)$, education $(\mathrm{OR}=2.7,95 \% \mathrm{CI}=1.5-4.6)$ and alcohol use $(\mathrm{OR}=1.8,95 \% \mathrm{CI}=1.2-3.0)$.

Conclusion: Road traffic crashes occurred commonly on bad roads, in the afternoon and during weekends, among young and uneducated long-distance drivers studied. Reconstruction of bad roads and implementation of road safety education programmes aimed at discouraging the use of alcohol and targeting the identified groups at risk are recommended. Keywords: Road traffic crashes, long distance drivers, mortality

\section{DOI: http://dx.doi.org/10.4314/ahs.v15i2.22}

\section{Introduction} glober a damage, that involves a motor vehicle in health problem of this century and are transport and occur on a traffic way or while the vehinow recognized as a neglected pandemic ${ }^{1}$. They ac- cle is still in motion after running off the traffic way. counted for $2.1 \%$ of total deaths and $21.0 \%$ of total Human, vehicular and environmental factors play roles injury globally ${ }^{2}$, and developing and underdeveloped before, during and after a crash event, therefore, RTCs countries accounted for $80 \%$ of these deaths ${ }^{3}$.

\section{Corresponding author:}

Adewale Moses Adejugbagbe

Department of Epidemiology

and Medical Statistics,

Faculty of Public Health,

University of Ibadan, Ibadan

Tel: 07030148970

Email: adewaleadejugbagbe@yahoo.com lof agent (person), host (vehicle) and environmental factors (infrastructure and climatic conditions), and analyzed in relation to time, place and person distribution $^{4}$. Human behavior and incapacitation account for over $85 \%$ of the contributing factors reported by a previous study in Africa ${ }^{3}$. Epidemiological research has tended to focus on human risk factors because they are relevant to the search for preventive measures, and because they have been identified as the most frequent cause of crashes ${ }^{5}$.

It has been reported that commercial vehicle drivers, in particular, young commercial drivers engaged in long

distance journeys are a major contributor to RTCs in- East, Ibadan South-West, Lagelu, Egbeda, Oluyole, cidents in Nigeria, and their impact on RTCs and eco- Ona-Ara and Ido park. A cluster sampling technique nomic losses are high ${ }^{6}$. Previous studies in Ibadan, was used to select 594 consenting commercial long-dissouth western Nigeria, had shown increase in RTC tance drivers from the motor parks in Ibadan in May, involvement among commercial intra-city and private 2013. Each of the motor parks represented a cluster. A drivers and had associated it with their behaviour ${ }^{7,8}$, but total of 5 clusters were selected from the 12 clusters in few have focused on the distribution and determinants Ibadan metropolis using simple random sampling techof RTCs among long distance drivers in this part of the nique. In the selected clusters, all long distance drivers country. This gap, the study intends to fill by explor- who met the eligibility criteria were approached and ing the conditions that made the long-distance drivers included in the study. A pretested interviewer-adminisprone to RTCs. This information could be used to de- tered semi-structured questionnaire was used to collect sign, implement and evaluate interventions to reduce data from the respondents on their characteristics, psythe risk of RTCs among them. Hence, the study was choactive substance use in their life time, life time and conducted to determine the prevalence of RTCs and one-year history of RTCs including place and time of describe the distribution of RTCs by place, time of oc- occurrence of the last crash in the previous one year currence, characteristics of persons involved, as well as before the study, and analysed using SPSS version 16 identify factors associated with involvement in RTCs with the level of significance set at 0.05 .

among long-distance drivers in Ibadan metropolis.

\section{Methodology} The the capital of Oyo State and the third largest metropoli- Transport Workers (NURTW) Ibadan before the comtan area by population in Nigeria after Lagos and Kano Participants included in the study were the long-distance commercial intercity vehicle drivers covering a distance of no less than $400 \mathrm{~km}$ per journey and in the twelve major motor parks in Ibadan. Those that did not consent or were not available during the interview days were excluded. The parks are located in each of the eleven local government areas in Ibadan, except Akinyele local government area, which has two parks. The other parks at each local government included; Ibadan North, Ibadan North-East, Ibadan North-West, Ibadan South-

\section{in May 2013}

Among the 594 long-distance motor vehicle drivers approached, 592 responded. The respondents were males with the median age of 42.0 years (range 22.0 -73.0years) (Table 1). Secondary education was the highest level of education attained by $38.0 \%$. Most $(88.2 \%)$ were married and $51.5 \%$ were Moslems. About $39.2 \%$ of them had been driving for more than 20 years. 
Table 1. Characteristics of long distance drivers in Ibadan in May 2013.

\begin{tabular}{|c|c|c|c|c|}
\hline & $\begin{array}{c}\text { Number of } \\
\text { Divers }(n=592)\end{array}$ & $\begin{array}{c}\text { Percentage } \\
(\%)\end{array}$ & Median & Mean \pm SD \\
\hline \multicolumn{5}{|l|}{ Gender } \\
\hline $\begin{array}{l}\text { Male } \\
\text { Female }\end{array}$ & 592 & 100.0 & & \\
\hline & \multicolumn{3}{|c|}{ Age } & \\
\hline $\begin{array}{l}\mathrm{Age} \\
20-29\end{array}$ & 33 & 5.6 & 42.0 & \\
\hline $30-39$ & 185 & 31.2 & & \\
\hline $40-49$ & 204 & 34.5 & & \\
\hline $50-59$ & 110 & 18.6 & & \\
\hline$\geq 60$ & 60 & 10.1 & & \\
\hline \multicolumn{5}{|l|}{$\begin{array}{l}\text { Educational } \\
\text { status }\end{array}$} \\
\hline Non- formal & 77 & 13.0 & & \\
\hline Primary & 290 & 49.0 & & \\
\hline Secondary & 225 & 38.0 & & \\
\hline \multicolumn{5}{|l|}{ Marital Status } \\
\hline Single & 30 & 5.1 & & \\
\hline Married & 522 & 88.2 & & \\
\hline Divorced/separated & 23 & 3.9 & & \\
\hline Widowed & 17 & 2.9 & & \\
\hline \multicolumn{5}{|l|}{ Religion } \\
\hline Christian & 281 & 47.3 & & \\
\hline Islam & 304 & 51.5 & & \\
\hline Tradition & 7 & 1.2 & & \\
\hline \multicolumn{5}{|l|}{ Tribe } \\
\hline Yoruba & 475 & 80.2 & & \\
\hline Igbo & 63 & 10.6 & & \\
\hline Hausa/Fulani & 49 & 8.3 & & \\
\hline Others & 5 & 0.8 & & \\
\hline \multicolumn{5}{|l|}{ Driving } \\
\hline \multicolumn{5}{|l|}{ Experience } \\
\hline & 22 & 3.7 & 17.00 & $18.1 \pm 9.0$ \\
\hline $5-9$ & 68 & 11.5 & & \\
\hline $10-14$ & 129 & 21.8 & & \\
\hline $15-19$ & 141 & 23.8 & & \\
\hline$>20$ & 232 & 39.2 & & \\
\hline
\end{tabular}

Psychoactive substance use among long distance ents in descending order were kolanut $38.5 \%$, 95\% drivers in Ibadan in May, 2013 $\mathrm{CI}=34.7-42.5 \%)$ alcohol $(34.0 \%, 30.2-37.8 \%)$ and

The substances most commonly used by the respond- cigarettes $(26.0 \%, 22.6-29.7 \%)$ (Table 2 ).

Table 2: Psychoactive substance used among long distance drivers in Ibadan in May,

\begin{tabular}{|c|c|c|c|c|}
\hline \multirow{2}{*}{$\begin{array}{l}\text { Psychoactive substance } \\
\text { used }\end{array}$} & \multirow{2}{*}{$\begin{array}{c}\text { Number of } \\
\text { Divers }(\mathrm{n}=592)\end{array}$} & \multirow[t]{2}{*}{ Percentage (\%) } & \multicolumn{2}{|c|}{$95 \%$ CI } \\
\hline & & & Lower & Upper \\
\hline \multicolumn{5}{|l|}{ Kolanut use } \\
\hline Yes & 228 & 38.5 & 34.7 & 42.5 \\
\hline No & 364 & 61.5 & & \\
\hline \multicolumn{5}{|l|}{ Cigarette smoking } \\
\hline Yes & 154 & 26.0 & 22.6 & 29.7 \\
\hline \multirow{2}{*}{\multicolumn{5}{|c|}{ Alcohol use }} \\
\hline & & & & \\
\hline Yes & 201 & 34.0 & 30.2 & 37.8 \\
\hline No & 391 & 66.0 & & \\
\hline
\end{tabular}

Experiences of RTCs among long distance drivers $\quad(46.8 \%), 95 \% \mathrm{CI}=37.0-57.0 \%)]$ of respondents who in Ibadan in May 2013 The lifetime prevalence of RTCs was $35.3 \%(95 \% \mathrm{CI}=$ years and $44 / 94(46.8 \%, 95 \% \mathrm{CI}=37.0-57.0 \%)$ re$31.5-39.2 \%)$ and $15.9 \%(95 \% \mathrm{CI}=13.1-19.0 \%)$ report- ported that the crash occurred in the afternoon. More ed having had at least one crash in the last one year than a quarter [40/94 (42.6\%), 95\% CI $=33.0 \%-52.7 \%$ ] preceding the study (Table 3). High proportion [44/94 of RTCs reported occurred during the rainy period.

\begin{tabular}{|c|c|c|c|c|}
\hline \multirow{2}{*}{ (n) } & \multirow{2}{*}{$\begin{array}{c}\text { Number of Divers } \\
(\mathrm{n}=592)\end{array}$} & \multirow{2}{*}{$\begin{array}{l}\text { Percentage } \\
(\%)\end{array}$} & \multicolumn{2}{|c|}{$95 \%$ CI } \\
\hline & & & Lower & Higher \\
\hline \multicolumn{5}{|l|}{ RTC in life time } \\
\hline Yes & 209 & 35.3 & 31.5 & 39.2 \\
\hline No & 383 & 64.7 & & \\
\hline \multicolumn{5}{|l|}{ RTC in 1 year } \\
\hline Yes & 94 & 15.9 & 13.1 & 19.0 \\
\hline No & 498 & 84.1 & & \\
\hline Age at last crash & $N=94$ & & & \\
\hline$<15$ & 1 & 1.1 & 0.0 & 5.1 \\
\hline $15-24$ & 9 & 9.6 & 4.8 & 16.8 \\
\hline $25-34$ & 33 & 35.1 & 26.0 & 45.2 \\
\hline $35-44$ & 44 & 46.8 & 37.0 & 57.0 \\
\hline$>45$ & 7 & 7.4 & 3.3 & 14.2 \\
\hline Time of last crash & $N=94$ & & & \\
\hline Morning & 11 & 11.7 & 6.3 & 19.4 \\
\hline Afternoon & 44 & 46.8 & 37.0 & 57.0 \\
\hline Evening & 19 & 20.2 & 13.0 & 29.2 \\
\hline Night & 19 & 20.2 & 13.0 & 29.2 \\
\hline Not specific & 1 & 1.1 & 0.1 & 5.1 \\
\hline $\begin{array}{l}\text { Climatic conditions at } \\
\text { last crash }\end{array}$ & $N=94$ & & & \\
\hline Raining & 40 & 42.6 & 33.0 & 52.7 \\
\hline Sunny & 37 & 39.4 & 30.0 & 48.5 \\
\hline Windy & 5 & 5.3 & 2.0 & 11.4 \\
\hline Others & 12 & 12.8 & 7.1 & 20.7 \\
\hline
\end{tabular}

The peak-day of occurrence of RTCs was on Saturdays [18/94 (19.1\%)] (Figure 1)

Figure 1: Days of occurrence of RTCs among long distance drivers in Ibadan in May 2013

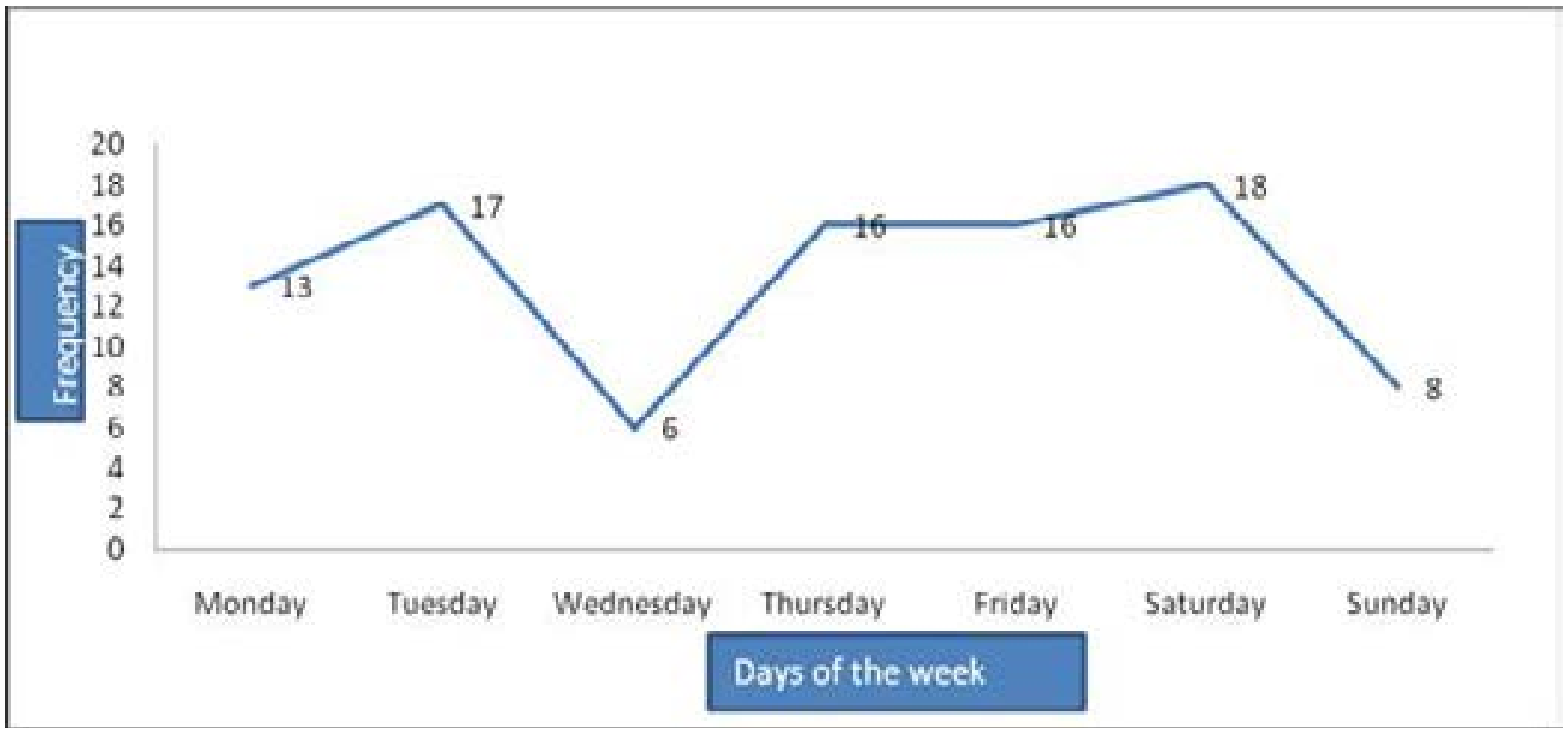

African Health Sciences Vol 15 Issue 2, June 2015 
The peak-months of occurrence of RTCs was on February [17/94 (18.1\%)] followed by March [15/94 $(16.0 \%)]$ (Figure 2).

Figure 2: Months of occurrence of RTCs among long distance drivers in Ibadan in May 2013

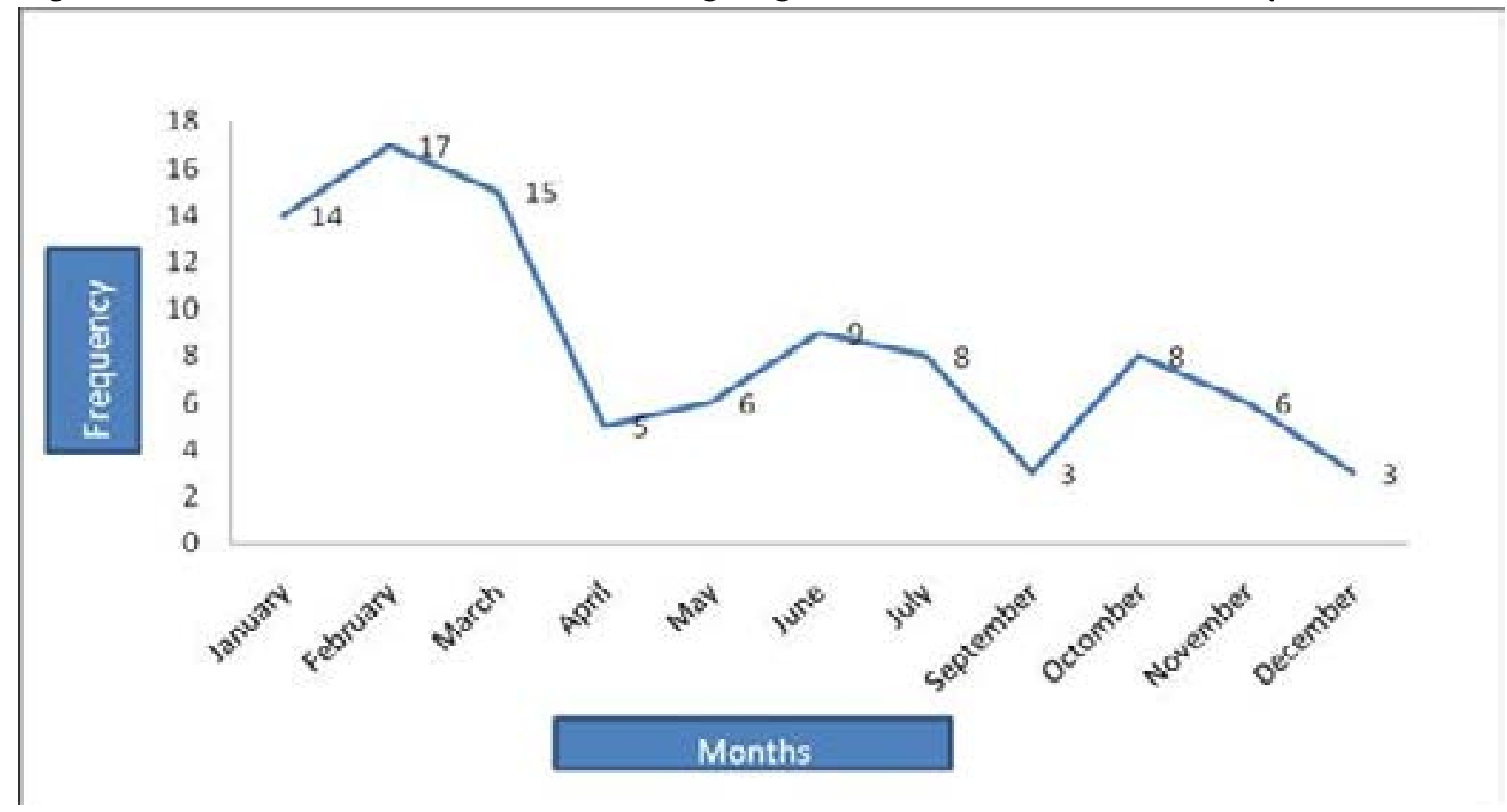

The RTCs occurred mainly on narrow roads $[32 / 94 \quad(34.0 \%)]$ and bad portions of tarred roads [35/94 $(37.2 \%)]$ (Figure 3).

Figure 3: Nature of the road during the last RTC among long distance drivers in Ibadan in May 2013

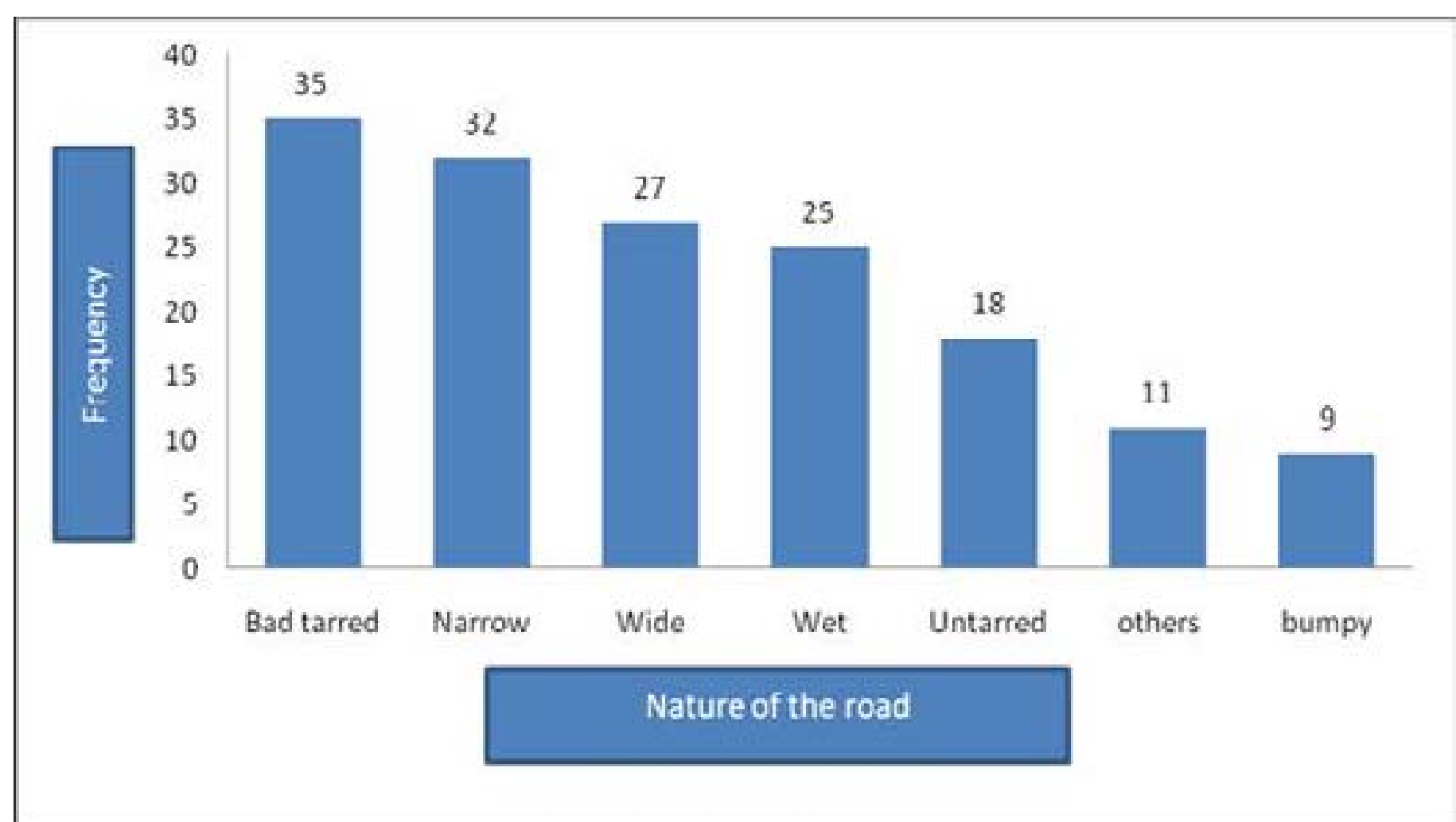

Poor road condition [45/94 (47.9\%)] was the highest lowed by mechanical fault [31/94 (33.0\%)] as shown in perceived cause of crashes reported in life time fol- Figure 4.

Figure 4: Antecedent causes of the last crash among long distance drivers in Ibadan in May 2013

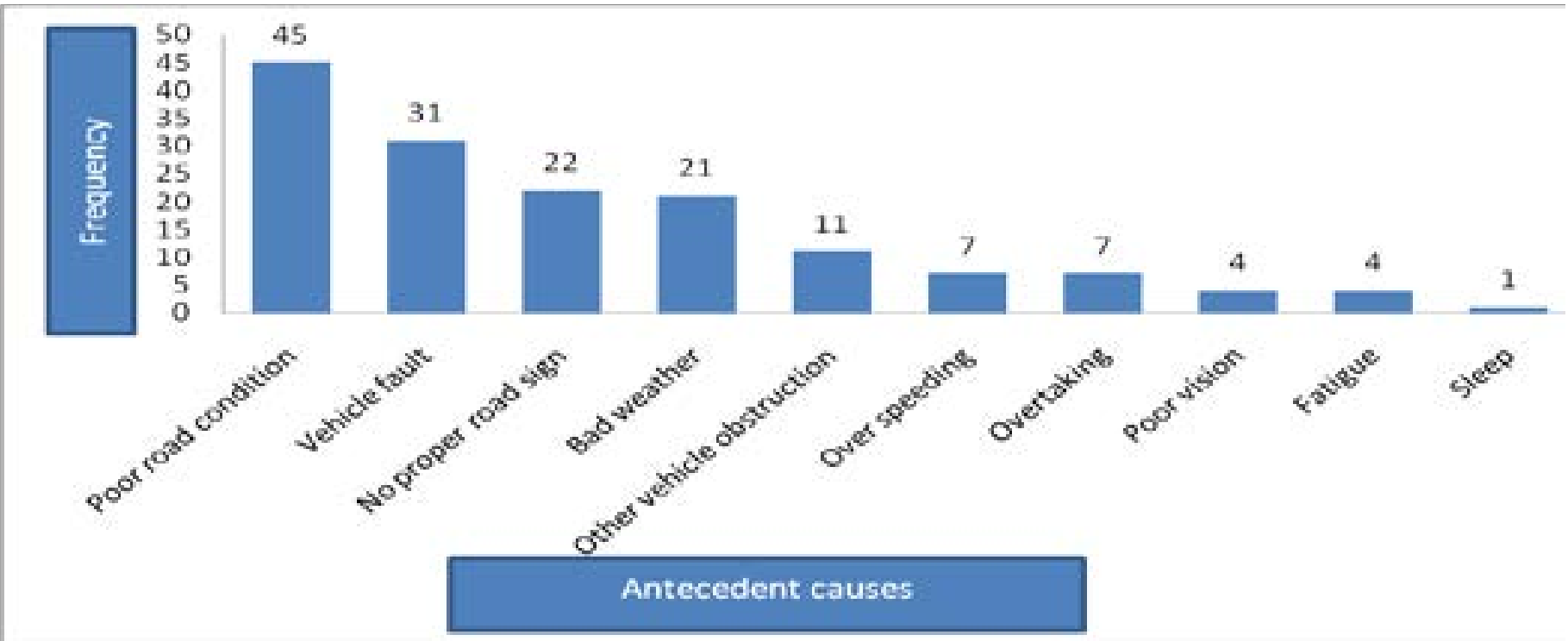

\section{*Multiple responses allowed}

Relationship between drivers' characteristics and tically significant (Table 4). About $23.4 \%$ of those $\leq 39$ occurrence of RTCs in the last one year among reported they had RTCs in the last one year compared long distance drivers in Ibadan in May $2013 \quad$ to those $>39$ years $(11.7 \%) \mathrm{p}=0.00$. More than a quarter In the exploration of the relationship between occur- $(29.9 \%)$ of those with no formal education reported rence of RTCs in the last one year and drivers' charac- RTCs in the last one year compared to those that were teristics, age-groups and educational status were statis- educated (13.8\%), $\mathrm{p}=0.00$.

\section{Table 4: Associations between drivers' characteristics and occurrence of RTCs in the}

\begin{tabular}{|c|c|c|c|c|c|}
\hline \multirow{2}{*}{$\begin{array}{l}\text { Demographic } \\
\text { Variables }\end{array}$} & \multicolumn{2}{|c|}{ RTCs in the last 1 year } & \multirow[t]{2}{*}{ Row Total } & \multirow[t]{2}{*}{$x^{2}$} & \multirow[t]{2}{*}{ P-Value } \\
\hline & $\begin{aligned} N o \\
n(\%)\end{aligned}$ & $\begin{array}{c}\text { Yes } \\
\text { n }(\%)\end{array}$ & & & \\
\hline \multicolumn{6}{|l|}{$\begin{array}{l}\text { Age groups in } \\
\text { years }\end{array}$} \\
\hline & $167(70.0)$ & $50(23.4)$ & 217 & \multirow[t]{3}{*}{13.2} & \multirow{2}{*}{0.00} \\
\hline$>39$ & $331(88.3)$ & $44(11.7)$ & 375 & & \\
\hline $\begin{array}{l}\text { Education } \\
\text { No education }\end{array}$ & & & & & \multirow{3}{*}{0.00} \\
\hline $\begin{array}{l}\text { No education } \\
\text { Educated }\end{array}$ & $\begin{array}{l}54(70.1) \\
444(86.2)\end{array}$ & $\begin{array}{l}23(29.9) \\
71(13.8)\end{array}$ & $\begin{array}{l}77 \\
515\end{array}$ & \multirow[t]{2}{*}{13.0} & \\
\hline $\begin{array}{l}\text { Marital Status } \\
\text { Single }\end{array}$ & & $10(333)$ & & & \\
\hline Married & $443(84.9)$ & $79(15.1)$ & 522 & \multirow{3}{*}{8.0} & \multirow{3}{*}{0.05} \\
\hline Divorced/Separated & $21(91.3)$ & $2(8.7)$ & 23 & & \\
\hline Widowed & $14(82.4)$ & $3(17.6)$ & 17 & & \\
\hline $\begin{array}{l}\text { Tribe } \\
\text { Yoruba }\end{array}$ & & $79(16.6)$ & 475 & \multirow{4}{*}{2.7} & \multirow{4}{*}{0.54} \\
\hline $\begin{array}{l}\text { Igbo } \\
\text { Igba }\end{array}$ & $57(90.5)$ & $6(9.5)$ & 63 & & \\
\hline Hausa/Fulani & $41(83.7)$ & $8(16.3)$ & 49 & & \\
\hline Others & $4(80.0)$ & $1(20.0)$ & 5 & & \\
\hline $\begin{array}{l}\text { Religion } \\
\text { Christianity }\end{array}$ & $239(85.1)$ & $42(14.9)$ & 281 & & \multirow{3}{*}{0.40} \\
\hline Islam & $252(82.9)$ & $52(17.1)$ & 304 & \multirow{2}{*}{1.8} & \\
\hline Traditional & $7(100.0)$ & $0(0.0)$ & 7 & & \\
\hline $\begin{array}{l}\text { Driving experience } \\
<10\end{array}$ & $107(81.1)$ & $25(18.9)$ & 132 & \multirow{3}{*}{2.1} & \multirow{3}{*}{0.34} \\
\hline $10-19$ & $190(83.3)$ & $38(16.7)$ & 228 & & \\
\hline$\geq 20$ & $201(86.6)$ & $31(13.4)$ & 232 & & \\
\hline
\end{tabular}


Relationship between psychoactive substance use use alcohol were involved in RTCs in the last one year and occurrence of RTCs in the last one year among compared to those that does not use $(12.8 \%), p=0.00$ long distance drivers in Ibadan in May 2013 (Table 5).

A significant proportion (21.9\%) of respondents who

Table 5: Relationship between psychoactive substance use and occurrence of RTCs in the last one year among long distance drivers in Ibadan in May 2013

\begin{tabular}{|c|c|c|c|c|c|}
\hline \multirow{2}{*}{$\begin{array}{l}\text { Psychoactive } \\
\text { substances }\end{array}$} & \multicolumn{2}{|c|}{ RTCs in the last 1 year } & \multirow[t]{2}{*}{ Total } & \multirow[t]{2}{*}{$x^{2}$} & \multirow[t]{2}{*}{ P-Value } \\
\hline & $\begin{array}{c}\text { No } \\
\text { n (\%) }\end{array}$ & $\begin{array}{c}\text { Yes } \\
\text { n (\%) }\end{array}$ & & & \\
\hline \multicolumn{6}{|l|}{ Cigarette smoking } \\
\hline No & $372(84.9)$ & $66(15.1)$ & 438 & 0.8 & 0.36 \\
\hline Yes & $126(81.8)$ & $28(18.2)$ & 154 & & \\
\hline \multicolumn{6}{|l|}{ Alcohol use } \\
\hline No & $341(87.2)$ & $50(12.8)$ & 391 & 8.2 & 0.00 \\
\hline Yes & $157(78.1)$ & 44 (21.9) & 201 & & \\
\hline \multicolumn{6}{|l|}{ Kolanut use } \\
\hline No & $313(86.0)$ & $51(14.0)$ & 364 & 3.2 & 0.12 \\
\hline Yes & $185(81.1)$ & $43(18.9)$ & 228 & & \\
\hline
\end{tabular}

Logistic regression association between drivers' alcohol use ( $\mathrm{OR}=1.8,95 \% \mathrm{CI}=1.2-3.0)$, age $\leq 39$ years characteristics and occurrence of RTCs in the last $(\mathrm{OR}=2.2,95 \% \quad \mathrm{CI}=1.4-3.5)$ and educational status one year among long distance drivers in Ibadan in $\quad(\mathrm{OR}=2.7,95 \% \mathrm{CI}=1.5-4.6)$ (Table 6).

May, 2013

Significant predictors of the last episode of RTCs were

Table 6: Logistic regression association between drivers' characteristics and occurrence of RTCs in the last one year in May, 2013

\begin{tabular}{lllll}
\hline & & & \multicolumn{2}{c}{$\mathbf{9 5 \%}$ Confidence interval } \\
\hline Variables & P- value & Odds ratio & Lower & Upper \\
\hline $\begin{array}{l}\text { Age in years } \\
\leq 39\end{array}$ & 0.00 & 2.2 & 1.4 & 3.5 \\
$>39$ & & & & \\
$\begin{array}{l}\text { Educational status } \\
\begin{array}{l}\text { Non educated } \\
\text { Educated }\end{array}\end{array}$ & 0.00 & 2.7 & 1.5 & 4.6 \\
$\begin{array}{l}\text { Marital status } \\
\text { Single }\end{array}$ & & & & \\
$\begin{array}{l}\text { Divorced } \\
\text { Widowed }\end{array}$ & 0.26 & 2.3 & 0.5 & 10.0 \\
$\begin{array}{l}\text { Married } \\
\text { Alcohol use }\end{array}$ & 0.78 & 0.8 & 0.2 & 3.0 \\
Yes & 0.41 & 2.5 & 0.1 & 3.0 \\
$\begin{array}{l}\text { No } \\
\text { Kolanut use }\end{array}$ & 0.06 & & & \\
Yes & 0.01 & 1.8 & 1.2 & 3.0 \\
No & & & & \\
\hline
\end{tabular}

We found that majority of the respondents were between 30 and 49 years of age. This age bracket is characterised by highly risky driving behaviours as reported by other authors ${ }^{4,9}$. Secondary school education was the highest level of education attained by $38.0 \%$ of the respondents in this study. This differs from findings by authors that have carried out similar work ${ }^{8,10}$. Similar to our study, Bamisoa et al. reported high prevalence $(35.7 \%)$ of alcohol use among long distance drivers in Ilorin, Nigeria?.

The one year prevalence of RTCs $(15.9 \%)$ in this study was higher when compared to the five year prevalence reported among drivers of a tertiary institution (11.1\%) and a teaching hospital $(4.0 \%)$ in a previous study in Ibadan $^{8}$. This marked disparity can be attributed to the differences in study population. The present study was on commercial drivers while the study in reference was on government drivers, who may be generally more careful and spend less time on the road. Significan high prevalence of RTCs was found among drivers that were $<40$ years of age even though they formed the minority group of the study participants. This can be attributed to the high risky behaviours among this category of drivers compared to the older ones. Previous authors have reported common risky behaviours such as over speeding, non-adherence to safety measures and high intake of psychoactive substances such as alcoho among this group of drivers ${ }^{11}$. Similar report has also been made in a previous study ${ }^{12}$

However, this is contrary to a report made by some other authors ${ }^{13}$. These differences may be related to driver's risk exposure, and this mainly has to do with a driver's annual mileage. Similar to our study, previous authors in Nigeria had reported significant proportion of RTCs among non-formally educated drivers compared to the educated ones, ${ }^{14}$ Significant proportion of those that used alcohol were involved in RTCs in the last one year and alcohol use was found to be a predictor of RTCs, its impairment has been identified as an important factor influencing both the risk of RTCs and the severity of injuries ${ }^{14}$.

In this study, highest prevalence of RTCs was reported in February and March, while the least was reported in August. Eke et al. reported that majority of the crashes occurred during the rainy season period (June, July

We found that RTCs occurred commonly on bad roads, my be explained by this association between RTCs and heavy traffics which occurs on the Nigerian roads during Christmas and new year festivities which span through the first (January, February and March) and last quarer (October, November and December) of the year. The highest prevalence of RTC reported occurred on Saturdays. This peak is probably due to the commune culture of travelling to attend social functions in villages during weekends, therefore, increasing traffic on the roads. Other reports indicated highest prevalence during the week days ${ }^{16}$. RTC had been found to occur regularly on narrow and bad roads ${ }^{7}$. The narrow roads represent single lane roads that could only be plied by one moving vehicle at a time, while bad roads include those with sharp bends, potholes and at bad sections of the highways. In our study, we found that RTCs reported occurred on narrow roads and bad portions of tarred roads, similar to previous reports ${ }^{7,16}$

Various causes have been reported as contributory to RTCs. Mechanical factors such as brake failure do occur but human factors are by far the most important in the causation of crashes. Atubi reported human factors as the most potent contributor to motor vehiculat dition as the highest perceived cause of crashes reportd in the last one year.

\section{Limitations} by the study design. For instance, RTCs were reported among survivors and those who were not severely disabled by the RTCs. Therefore, information may not have been obtained on many fatal and severe crashes, thereby providing an underestimation of the burden of the crashes. In addition, association found may have been influenced by survival bias. The survey relied on the reports of respondents which could not be independently validated. There was a tendency to underreport crashes due to poor recall, thus the findings of the study may be influenced by recall bias. The study, however, provided an insight into the burden as well as risk factors of RTCs in the studied area, upon which some specific interventions could be suggested and subsequently crashes in Nigeria ${ }^{17}$, however, we found poor road con-

The findings from this study could have been limited evaluated, if they are implemented. 
in the afternoon and weekends; and among young and uneducated long distance drivers. There is a need for repair and reconstruction of bad roads, including proper design of road networks and implementation of road safety education programmes aimed at discouraging the use of alcohol and targeting the identified groups at risk.

\section{Authors' contributions}

All the authors were involved throughout the course of the study. Adejugbagbe A. and Fatiregun A. conceived the study. Initial draft was done by Adejugbagbe A. and and approved by all authors.

Conflict of interest: None

\section{References}

1. Dinesh M. Road traffic injuries-a neglected pandemic. Bull World Health Organ 2003; 81(9): 684-685.

2. World Health Organisation. World report on road traffic injury prevention. WHO. 2004. Geneva. Switzerland. Retrieved September, 03, 2014, from http://www. who.int/violence_injury_prevention/publications/ road_traffic/world_report/en/index.html

3. Peden M, Scurfield R, Sleet D, Mohan D, Hyder AA. World report on road traffic injury prevention: Summary. WHO. 2004. Geneva. Switzerland. Retrieved May, 22, 2007, from http:/www.who.int/world-healthday/2004/infomaterials/world_report/en/

4. Mishra B, Sinha Mishra ND, Sukhla S, Sinha A. Epidemiological study of road traffic accident cases from Western Nepal. Indian J Community Med 2010;35(1):11521.

5. Hendricks DL, Fell JC, Freedman M. The relative frequency of unsafe driving acts in serious traffic crashes. National Highway Traffic Safety Administration, US Department of Transport Summary Technical report. Retrieved September, 03, 2014, from http//www.nhsta. dot.gov/people/injury/research/UDAshortrpt/index. html

6. World Health Organisation. Global status report on road safety: time for action. WHO. 2009. Geneva. Switzerland. Retrieved September, 03, 2014, from www. who.int/violence_injury_prevention/road_safety_status/2009/en/

7. Bekibele CO, Fawole OI, Bamgboye AE, Adekunle
LV, Ajav R, Baiyeroju AM. Risk factors for road traffic accidents among drivers of public institutions in Ibadan, Nigeria. Afr Health Sci 2007;14(3):137-142.

8. Bekibele CO, Fawole OI, Bamgboye AE, Adekunle LV, Ajayi R, Baiyeroju AM. Prevalence of refractive error and attitude to spectacle use among drivers of public institutions in Ibadan, Nigeria. Ann Afr Med 2007;6(1):26-30.

9. Makanjuola BA, Oyeleke SA, Akande TM. Psychoactive Substance Use among Long Distance Vehicle Drivers in Ilorin, Nigeria. Nig J Psychiatry 2007;5(1):14-18. 10. Johnson OE, Adebayo AM. Effect of safety education on knowledge of and compliance with road safety signs among commercial motorcyclist in Uyo, Southern Nigeria. Ghana Med J 2011;45(3):89-96.

11. Palamara P, Molnar L, Eby D, Kopinanthan C, Langford J, Gorman J, Broughton M. Review of young driver risk taking and its association with other risk taking behaviours. Transportation research institute 2012; Report 1:1-179. Retrieved September, 17, 2014 from http://deepblue.lib.umich.edu/bitstream/2027.42/94210/1/102889.pdf

12. Adogu PO, Ilika AL, Asuzu AL. Predictors of road traffic accident, road traffic injury and death among commercial motor cyclist in an urban area of Nigeria. Niger J Med 2009;18(4):393-397.

13. El Chliaoutakis J, Demakakos P, Tzamalouka G, Bakou V, Koumaki M, Darviri C. Aggressive behavior while driving as predictor of self-reported car crashes. $J$ Safety Res 2002; 33(4):431-443.

14. Odero, W. Alcohol-related road traffic injuries in Eldoret Kenya. East Afr Med J 1998;75(12):708-711.

15. Eke N, Etebu EN, Nwosu SO. Road traffic accident mortalities in Port Harcourt, Nigeria. Anil Aggrawal's Internet J Forensic Med Toxicol 2000; 1 (2). Retrieved September, 17, 2014 from http://www.anilggrawal. com/iij/vol_001_no_002/paper006.html

16. Singh A, Bhardwaj A, Pathak R, Ahluwalia SK. An Epidemiological Study of Road Traffic Accident Cases at a Tertiary Care Hospital in Rural Haryana. Indian J Comm Health 2011; 23(2):53-55.

17. Atubi AO. Determinants of Road Traffic Accident Occurrences in Lagos State: Some Lessons for Nigeria. International Journal of Humanities and Social Science 2012; 2(6). 252-259. 